\title{
ÇALIŞANLARIN ÖRGÜTSEL BAĞLILIĞINI ETKİLEYEN FAKTÖRLER ÜZERİNE PROJEKTİF BİR ÇALIŞMA
}

\author{
Aytuğ MERMER ÜZÜMLÜ*
}

\section{ÖZET}

Küreselleşme ile birlikte değişen pazar öncelikleri, teknolojik dönüşüm, rakip tehditleri gibi unsurlar örgütlerin sahip olduğu insan kaynağının değerinin altını her geçen gün çizerken, yöneticiler için örgütün hedefleri doğrultusunda tecrübe kazanmış çalışanlar ile yola devam etmek önem kazanmaktadır. Hâlihazırdaki insan kaynaklarının etkin kullanımı çoğu zaman kurum içi iletişim uygulamalarının bir parçası olarak ele alınmaktadır. Bu bağlamda çalışanların motivasyonu, birbirleri ve yöneticiler ile ilişkilerinin olumluluğu ve sürekliliği iç halkla ilişkiler çabalarının başarılılığının da bir göstergesi olarak kabul edilmektedir. Fakat kurum her ne kadar örgütsel bağl1lığ oluşturmak ve sürdürmek için kurumsal iletişimde başarılı politikalar yürütse de, çalışanların sahip olduğu kimlik özellikleri onların örgütsel bağlllığına etki eden önemli bir faktördür. Bu çalışma işgören sirkülasyonun salt örgütsel halkla ilişkiler çabalarının yetersizliği olarak değerlendirilmemesi gerektiği, bireysel unsurların da çalışanların örgütsel bağlılığında etkin bir konumda olduğu iddiasını taşımaktadır. Bunun için çalışmada 200 çalışana anket uygulanmıştır. Anket soruları işgörenlerin Allen ve Meyer tarafından belirlenen örgütsel bağl1lık türlerini oluşturan duygusal bağl1lık, devam bağl1lığ ve normatif bağlılıktan hangisine daha eğilimli olduğunu ortaya koymaya yönelik hazırlanmış, bu eğilimi ortaya çıkaran kimlik özelliklerinin ve dış koşulların kısmen neler olduğu belirlenmeye çalışılmıştır. Çalışma Amasya ilinde özel sektörde faaliyet gösteren örgütlerde çalışanların değişen koşullar karşısında örgütsel bağlılık davranışlarını belirleyen kıstasın ne olduğunu projektif tekniklerden sembolik analoji tekniği ile keşfetmek amacını taşımaktadır. Çalışma sonucu işgörenlerin örgütsel bağlılığını etkileyenin önemli ölçüde bireysel kimlik özellikleri olduğunu ortaya çıkarmakla beraber, örgütsel bağl1lığı sağlamak için kurumsal uygulamaların da etkin bir konumda olduğunu göstermektedir.

Anahtar Sözcükler: Örgütsel bağlllık, kimlik, kurumsal iletişim, halkla ilişkiler

\section{A PROJECTIVE STUDY ABOUT THE FACTORS AFFECTING ORGANIZATIONAL COMMITMENT OF EMPLOYEES}

\begin{abstract}
While globalization, the change of market priorities, technological transformation and rival threats emphasize the value of human resources of organizations, that is important for executives to continue their business life together who have gained experience in line with the objectives of the organization. The effective use of surrent human resources is often considered as part of internal communication practices. In this context, the motivation of employees, good relationship with other employees and continuity of their relations with managers are accepted as an indicator of the succes of the internal public relation efforts. Even though the organization conducts successful policies in corporate communication to establish an maintain organizastional commitment, identity characteristics of employees are an important factor affecting the organizational commitment. Inthis stuty, the fact that

* Dr. Öğr. Üyesi, Amasya Üniversitesi, Sosyal Bilimler MYO, Pazarlama ve Reklamcılık Bölümü, aytug.mermer@amasya.edu.tr. ORCID: 0000-0001-6410-4974, Makalenin Geliş Tarihi: 25.06.2019Makalenin Kabul Tarihi: 27.10.2019.
\end{abstract}


employee circulation is not considered to be the inadequacy of organizational public relations efforts also asserts that individual elements are also effective in the organizational commitment of employees. For this purpose, a questionnaire was applied to 200 employees. The questions were prepared to reveal which of the employees' affective commitment, continuance commitment and normative commitment scale, which are the types of organizational commitment determined by Allen and Meyer, and the identity characteristics that reveal this tendency are partially determined. The aim of this study is to find out the criterion that determines the organizational commitment behaviors of the employees in the private sector organizations in Amasya with the help of symbolic analogy technique. As a result of the study, it is found out that the effects of employees' organizational commitment are significant individual identity characteristics, but also that institutional practices are in an effective position to ensure organizational commitment.

Keywords: Organizational commitment, identity, internal communication, public relations

\section{Giriş}

Nitelikli insan kaynağının örgütsel sermayenin vazgeçilmezleri arasında yerini alması şimdilerde birçok kurumun kabul ettiği bir gerçektir. $\mathrm{Bu}$ nedenle çalışanlarına gelecek garantisi sunarak onları rahatlatan, demokratik bir biçimde yönetim politikalarına onların da katkıda bulunması için ortam oluşturan, çalışanların hâlihazırda sahip oldukları yetenekleri açığa çıkaracak koşulları yaratan, özlük hakları terfi ve ödül politikaları ile çalışanların kariyer hedeflerine ulaşmalarını destekleyen örgütler işgören sirkülâsyonundan olumsuz olarak etkilenmemek konusunda diğer örgütlere oranla daha avantajlı konumda bulunmaktadır. Zira bahsi geçen koşullarda çalışan bireyler kendilerini değerli ve kuruma ait hissetmektedir. Çalışanlar kendilerini örgüte ait hissettikçe sadece iş tanımlarında bulunan görevleri yerine getirip maddi karşılıklarını almaktan öte, kendi sorumluluk alanlarına dâhil olmayan konularda da inisiyatif alıp, örgütün ortak hedef ve amaçlarını benimseyerek örgüt çalışanı olmaktan menkul bir kolektif kimlik yaratmaktadır.

Bahsi geçen döngüsel sürecin başlangıcında yöneticilerin izlediği iletişimsel politikaların rolü büyük olmakla beraber bu politikalar tek başına çalışanların örgüte bağlanmasına neden olmamaktadır. Örgütsel bağlılık kimi zaman dış koşullarla oluşan, kimi zaman içsel olarak ortaya çıkan bir tutumdur. Bu tutuma kaynaklık eden bağlılık türleri bulunmaktadır. Allen ve Meyer tarafından 1990 yılında ortaya konan ve Meyer, Allen ve Smith tarafindan 1993 yılında revize edilerek son halini alan üç bağlılık türü, literatürde en yaygın kabul gören sınıflandırmadır. Bu bağlılık türleri, duygusal bağl1lık, devam bağ l1lığ 1 ve normatif bağl11ıktır.

Çalışanların örgütsel bağlılığını etkileyen bu üç bağlılık türü her ne kadar, arzu, ihtiyaç ve yükümlülük ekseninde ifade edilirken sınırları net bir biçimde çizilse de, kişilerin tutum ve davranışlarında bulduğu yansımanın temeli her durumda kişi ve örgüt tarafindan net bir biçimde çözümlenememektedir. Kimi zaman çalışanlar değişen koşullar altında bu üç bağlılık türünden her birini değişen oranda deneyimleyebilmektedir (Wasti, 2003: 303). Dolayısıyla işgörenlerin bahsi geçen üç bağl1lık türünden tek biri ile bir örgüte bağlanması mümkün görülmemekte, 
koșullar değiștikçe bireylerin bağlılık türleri de değișmektedir. Bu çalıșmanın amacı işgörenlerin farklı olaylar ve durumlar karşısında hangi bağlılık türüne yakın eğilim gösterdiklerini ortaya çıkarmaktır. Çalışmada projektif tekniklerden sembolik analoji tekniği uygulanmıştır. Bu tekniğin seçilme sebebi çalışmanın amacı ile uyumlu olarak katılımcıların sorular direkt olarak sorulduğunda otomatik ve toplumsal doğrular temelli (fakat kendi uygulamadıkları) davranışları gerçekleştirdiklerini ifade etme ihtimaline karşın yansıtma sorular ile kişilerin kendilerini farklı durumlar içinde düşünerek o koşullar altında nasıl bir tepki sergileyeceklerini ifade etmelerini isteyerek davranışların gerçek sebebine ulaşmaktır. Bu anlamda çalışma kurum içi iletişim, kolektif kimlik, örgütsel bağlılık ve motivasyon temelli araştırmalar yapan halkla ilişkiler literatürüne katkı sunmaktadir.

\section{1. Örgütsel Bağlılık}

Örgütsel bağl1lık ifadesini ilk kez akademik yazında kullanan Becker (1960: 32-33) kavramı örgütten yana "bilinçli bir biçimde taraf tutma" olarak tanımlamakta ve bu bilinçli bağlılığı işin kendisine bağlılık, çalışma arkadaşlarına bağlılık ve kurumun tümüne bağlılık olarak birbirinin aşamaları olacak düzeyde sübjektif bir tavır olarak ele almaktadır. Becker'i takip eden dönemde alandaki çalışmalar bu muğlâk kavrama kapsayıcı tanımlar yapma çabası taşımaktadır.

Erken dönem çalışmalarda genel eğilim örgütsel bağlılığın, örgütün hedef ve değerlerini benimsemek, örgütün bir parçası olmak için çaba göstermek ve güçlü bir aile üyesi gibi hissetmek davranışları üzerinden tanımlanmasıdır (Steers, 1977: 46). Zaman içinde örgütsel bağlılık, davranışsal çıktılardan öte his ile bağlantılandırılmakta ve Davis ve Newstrom'un (1989: 179) da ifade ettiği şekliyle, bireysel ve içkin bir zeminden hareketle işgörenin kurum ile kimliğini örtüştürerek, kurumun aktif bir üyesi olarak kalmak yönündeki isteği olarak tanımlanmaktadır. Leong (1996: 1345) ise örgütsel bağlılı̆̆1 kolektif kimlik boyutuna taşımakta ve "kişinin belirli bir örgüt ile girdiği kimlik birliği ve bağlılığın birleşik gücü" olarak ifade etmektedir. Benzer şekilde Svvailes'de (2002: 159) örgütsel bağl1lığ1, örgütün amaçlarına gönülden inanıp kabullenme, bu amaçlara ulaşmak için tüm gücünü sarf etmeye rıza gösterme ve örgütün üyesi olma halini sürdürmek için güçlü bir irade ortaya koyma olarak tanımlamaktadır.

Çalışanların örgüt üyeliğini içselleştirerek kendini kolektif bir kimliğin parçası olarak görmesi, hem çalışanın kendini daha erdemli hissetmesine, hem de örgütsel etkinliğinin artmasına yol açmakta, bu durum çalışana da örgüte de yarar sağlamaktadır. Benzer şekilde iş kaybı endişesi taşımayan çalışan kendini örgüte daha ait hissederek daha verimli iş görürken, örgüt de yetişmiş iş gücü kayb1 endișesi yaşamamaktadır. Örgütsel bağlılık bu anlamda örgütsel temelde ișten ayrılma, işi yavaşlatma, devamsızlık gibi davranışları da engelleme potansiyeline sahiptir. 
Örgütsel bağlılığın göstereni olan davranışlar ile çalışanın içsel olarak hissettiğgi duyguların kaynakları farklı düşünürler tarafindan kategorize edilmektedir. Stum (1999: 6), örgütsel bağlılığın oluşması için yüksek maaş ve prim gibi maddi çıkarların yanı sıra, çalışanın örgüt içinde yükselebilme olanakları, liderin örgüt kültüründe olumlu bir tavrı ve bireysel düzlemde sadık olma halinin bulunmasının gerektiğini iddia etmektedir. Mowday vd. örgütsel bağlılığı en genel haliyle ikiye ayırmakta ve hislerle ilgili kısmını duygusal bağlılık ve davranışlarla ilgili kısmını tutumsal bağlılık (akt: Iverson,1998: 2) olarak tanımlamaktadır. Kanter (1968) alışkanlık ile oluşan devamlılık bağlılığı, ortak hedefleri içselleştirmekle oluşan bağdaşım bağlılığı ve denetim mekanizmaları eliyle oluşturulan kontrol bağlılığ1 sınıflamasını yapmaktadır. Benzer şekilde O'Reilly ve Chatman (1986) da uyum (compliance) bağlılığ , kimlik özdeşleşme (identification) bağ lılığ ve içselleştirme (internalization) bağlılığ kategorizasyonları ile literatüre katkıda bulunmaktadır. Etizoni de örgütsel bağlılı̆ğ üç sınıfta ele almaktadır. Ona göre (akt: Zangaro, 2001: 15) içsel olarak motivasyon yaratan ahlaki bağlılık, çıkarlarla temellendirilmiş hesapçı bağlılık ve örgüte dahil olmayanların dezavantajlarını göz önünde bulunduran yabancılaştırıcı bağlılık türlerinden biri ile çalışan örgütsel bağlılık tutumunu güçlendirmektedir. Bu sinıflandırma çabaları "genelde örgüt ile çalışan arasında bir bağ bulunduğunu, fakat bu bağın niteliğinin farklı kaynaklardan temellendirildiğini ifade etmek için yapılmaktadır" (Allen ve Meyer, 1990: 3). Tüm bu çalışmalar arasında kapsayıcılığı ile literatürde en yaygın olarak tercih edilen örgütsel bağlılık türleştirmesi Allen ve Meyer (1990) tarafından yapılmakta ve duygusal bağlılık, devamlılık bağ lılığı ile normatif bağ lılık sınıflarına ayrılmaktadır.

\section{1. Örgütsel Bağlılık Türleri}

Allen ve Meyer'ın (1990) türleştirmesi akademik yazında yer bulduğu günden bugüne yapılan birçok araştırmada temel sınıflandırma olarak kabul edilmektedir. $\mathrm{Bu}$ model kısaca, "duygusal bağlılığı bireylerin istedikleri için örgütte kaldığını, devamlılık bağlılığını bireylerin ihtiyacı olduğu için örgütte kaldığını ve normatif bağl1lığı ise bireylerin örgütte kalmak zorunda olduklarını düşündükleri için örgütte kaldığını ifade etmek için kullanılmaktadır" (Zangaro, 2001: 16).

\subsubsection{Duygusal (Affective) Bağlılık}

$\mathrm{Bu}$ bağlılık türü, çalışanların his bağı ile örgüte bağlanarak kimliklerinde bir özdeşleşme yaratmaları ve bu sebepten örgütte kalmayı istemeleri olarak tanımlanmaktadır (Allen ve Meyer, 1996: 253). Duygusal kaynaklı örgütsel bağlılık tutumuna sahip bireyler, örgütün çıkarlarını kendi çıkarlarıymışçasına benimseyerek bu hedeflere ulaşılması için yoğun oranda çaba göstermekte ve bu çabayı sadece istedikleri için sergilemektedirler. Bu çalışanlar örgüte dair başarı ve başarısızlık durumlarından bireysel olarak kendilerini sorumlu hissetmektedir. Starnes ve Truhon'a (2006: 3) göre duygusal olarak bağl1lık geliştiren çalışanlar işe yönelik olumlu bir tutuma sahip, örgütte kalma halini sürdürmeye istekli ve yüksek düzeyde performans gösteren kişilerdir. 
$\mathrm{Bu}$ anlamda duygusal bağlılık, işgörenle örgütün amaç ve değerlerinin bütünleşmesi sürecinde aktif bir katılımı ifade etmektedir (Doğan ve Kılıç, 2007: 44). Bu yüzden duygusal bağl1lık, örgütlerde gerçekleşmesi en çok arzu edilen ve çalışanlara aşılanmak istenen bağlılık türüdür (Afşar, 2011: 10). Çalışanların duygusal bağglılık geliştirebilmesi için örgütlerin bazı konularda düzenlemeler yapmalarının gerekliliğinin altını çizen Kaygısız'a (2012: 28) göre duygusal bağlılığın oluşumu için örgütte ve kişide bazı özelliklerin bulunması gerekmektedir. Bunlar; çalışanın mücadele gerektiren ve herkesin yapamayacağını düşündüğü bir işe sahip olması, çalışanın örgütteki rolünün ve pozisyonun açıkça belirtilmiş olması, çalışana örgütün hedeflerine ulaşmadaki amacının net bir biçimde belirtilmiş olması, diğer çalıșanlarla arasında arkadaș bağlılığı olması, yönetimin çalıșanların fikirlerini dikkate alması ve kararlara katılımın sağlanması, yönetimsel düzeyde çalışanlara adil davranılması, örgütün çalışanlarına sahip çıktığının bilinmesi, performansının dikkate alındığının bilinmesidir. Böylelikle birey örgüt içinde konumunun gerektirdiği eylemden fazlasını ortaya koyma çabasını sürekli olarak sergilemektedir (De Loria, 2001: 23). Fakat örgütte bahsi geçen koşullar oluşmadığ1 takdirde de duygusal bağlılık gelișebilmektedir. Zira "duygusal bağlılık kişilik özellikleri ile ilgili tutumsal bir olgudur ve örgütsel hedefleri destekleme yönünde çalışanların gönüllülüğü esasına dayanmaktadır" (Mir vd., 2002: 190). Duygusal bağl1lığa temel oluşturan kişilik özellikleri dış etkenlerden yüksek düzeyde etkilenmemekle beraber, kişilerin yaşam öncelikleri ile ters düşen durumlarda aksi bir görüntü yaratabilmektedir.

\subsubsection{Devam (Continuance) Bağlılığı}

Çalışanların hâlihazırdaki işlerinden ayrılma durumunda oluşacak maliyetlerin farkına vardıkları için örgütlerine bağlılık geliştirmesini ifade etmektedir (Allen ve Meyer, 1996: 253). Devam bağlılı̆̆ yüksek olan çalışanlar yeni iş olanaklarının sınırlılığı düşüncesiyle var olan işlerindeki özlük hakları ve finansal kazanımlarını kayıptan kaçınmak için işe devam etmektedirler. Bu çalışanlar "örgüt üyeliğini sürdürmek için gerekli asgari çalışma düzeyinde performans sergilerler ki, bu örgütler açısından istenmeyen bir bağlılık türüdür" (Afşar, 2011: 10).

Devam bağlılığına sahip bireylerin örgütsel bağlılığını belirleyen kıstaslar durumsal olarak değişiklik göstermektedir. Eğer çalışan hâlihazırdaki nitelikleri ile başka bir örgüte kabul edilebilirse (yetenek transferi), mevcut eğitimi başka bir örgüt için uygunsa (eğitim transferi), var olan işindeki pozisyonu için yüksek oranda çaba harcadıysa (kendine yatırım), mevcut işinden ayrıldığında yer değişikliği yaşayacaksa (yeniden yerleşme), işten ayrıldığında hak kaybına uğrayacaksa (tazminat kaybı), örgütten ayrılması halinde sahip olduğu pozisyondan daha iyisini bulacaksa (alternatif iş imkânları) hesaplamaları neticesinde çalışmaya devam kararını şekillendirmektedir (Allen ve Meyer, 1990: 9)

Dolayısıyla devam bağlılığına sahip bireyler araçsalcı bir bakış açısıyla sürekli fayda maliyet hesabı yapmaktadır ve onları örgüte bağlayan, kalma kararlarını etkileyen psikolojik durum yaptıkları hesaplamalar neticesinde ortaya çıkmaktadır 
(Obeng ve Ugboro, 2003: 84). Bu bireyler, yalnızca örgüt tarafından sunulan ödüller kendi beklentileriyle örtüştüğünde yüksek düzeyde performans sergilemekte (Starnes ve Truhon, 2006: 3), diğer zamanlarda örgütsel hedeflere ulaşmak için asgari limitlerini zorlamamaktadırlar.

\subsubsection{Normatif (Normative) Bağlılık}

Çalışanın örgüte duyduğu bağlılığın kaynağını içsel bir zorunluluktan aldığı bağlılık türüdür (Allen ve Meyer, 1996: 253). Normatif bağlllık geliştiren bireyler kuruma bağlılıklarını erdemli kimliklerinin bir uzantısı olarak görmektedir. Çalıştıkları örgütte işlerini yapmak onların görevidir ve görevini yerine getirmek "doğru" bir davranıştır. Diğer bir ifade ile "normatif bağlılık, bireylerin kişisel sadakat normları ile ilişkili olup temellerini onların sosyal ve kültürel özelliklerinden almaktadır" (Afşar, 2011: 10).

Normatif bağlılık, işgörenin işverenine sadık kalmasının zaten olması gereken bir durum olduğu yönünde sosyalizasyon geliştirmiş bireylerde görülmekte ve "örgütte kalmayı ahlaki ve doğru olarak niteleyen inanca dayalı bir sorumluluk duygusunu ifade etmektedir" (Özcan, 2011: 58). Modernleşme ile yeniden şekillenen toplumsal yapının normatif bağlılık oluşması için gereken yazılı olmayan kurallarla bezenmiş olarak "örgütsel kimlik" oluşumuna zemin hazırladığına dikkat çeken Wiener (1982: 423-424) "milletlerin toplumsal ve kültürel değerlerinin, ahlaki boyut çerçevesinde çalışanların işten ayrılma niyetlerini azaltarak normatif bağlılık üzerinde etkili olduklarını" zikretmektedir.

Dolayısıyla normatif bağlılık, bireylerin örgüte sadık olma hallerinin beklenen davranış standartlarına uyması ile gelişmektedir. "Bu kişiler itaat, ihtiyatlılık ve formaliteye değer vermektedir. Araştırmalar bu kişilerin duygusal bağl1likta bulunanlarla aynı tutum ve davranışları sergileme eğiliminde olduğunu göstermektedir" (Starnes ve Truhon, 2006: 3). Çoğu zaman kişiler o işe girmeden önce genel anlamda çalışacakları tüm işlerine bağlı olmaları konusunda bir içsel yükümlülüğe sahiptirler.

\section{Yöntem ve Metodoloji}

\subsection{Kapsam ve Sinırlılıklar}

Çalışmanın uygulama kısmı Amasya ilinde özel sektörde aktif olarak çalışanlar ile gerçekleştirilmiştir. Dolayısıyla sonuçların ülke genelini yansıtacak şekilde yorumlanması sorun yaratabilir. Benzer şekilde iş kaybı ihtimalinin ve iş değişikliğinin özel sektöre oranla düşüklüğü, terfi ve ücret politikalarının değişkenlik göstermemesi gibi nedenlerle kamuda çalışanlar araştırmaya dâhil edilmemiştir. $\mathrm{Bu}$ sebeple sonuçların kamuda çalışanları içerecek şekilde yorumlanması geçerlilik anlamında sorun yaratabilecektir. Katılımcıların anket formlarını okuduğu, anladığı ve nesnel bir biçimde cevap verdiği varsayılarak 200 anket formu değerlendirmeye alınmıştır. 


\subsection{Araştırmanın Modeli}

Çalışmanın uygulama bölümünde kalitatif bir veri toplama yöntemi olan projektif tekniklerden sembolik analoji tekniği seçilmiştir. Analoji bir olayı örnekler vererek ve benzetmeler üzerinden ifade etme şeklidir (Dinçer, 1995) "Sembolik analoji (benzetim) tekniğinde katılımcılara araştırmaya konu olan bir ürün, markanın, bir kişi, obje ya da duygu olarak düşünüldüğü varsayılarak bunlardan hangisini temsil ettiği ya da tam aksi sorulmaktadır" (Hague ve Jackson 1999: 128). Anket uygulanırken katılımcıların gizli düşüncelerini, duygularını ve bunun arkasında yatan güçleri bilmenin önemini vurgulayan Zaltman (2014) kişilerin düşüncelerini iletmesinde bilindik sözlerin kullanılmasının bütün parametreleri ortaya çıkarmada yeterli olmadığını ifade etmektedir. Bu sebeple gizil duyguları ortaya çıkarmada projektif tekniklerden yardım alınmaktadır (Koll vd., 2010: 589). Sorular katılımcıların hayal dünyasını uyandırdığından, cevaplar direkt sorulan soruların cevaplarına oranla daha özgür ve samimi bir anlayışla verilmektedir.

\subsection{Araştırmanın Örneklemi}

Araştırmanın örneklemi Amasya ilindeki turizm, tekstil, gıda ve otomotiv sektörlerinde (beyaz ve mavi yakalı) çalışanlardan oluşmaktadır. Örneklem seçimi tesadüfî olmayan yöntemlerden kolayda örnekleme ile oluşturulmuştur. Örnekleme dahil edilecek katılımcı sayısı belirlenirken, Comrey ve Lee'nin (1992) faktör analizi için örneklem sayısının 50 çok zayıf, 100 zayıf, 200 orta, 300 iyi, 500 çok iyi olduğu ve Kline'nin (1994) örneklem sayısının soru formundaki madde sayısının 10 katı olmasının iyi olacağı fakat her halükarda güvenilir faktörler ortaya koymak için 200 kişilik örneklem büyüklüğünün yeterli olacağı yönündeki önerileri (akt: Büyüköztürk, 2011) dikkate alınmıştır. Bu doğrultuda toplamda 228 anket formu dağıtılmış bunlardan 212 tanesi geri toplanabilmiştir. Toplanan anket formlarından 12 tanesi açık uçlu soruların okunamaması, bazı soruların yanıtsız bırakılması gibi nedenlerle geçersiz bulunmuş, 200 kişilik örneklemden elde edilen veriler analize tabi tutulmuştur.

\subsection{Veri Toplama Aracı}

Araştırmada veri toplama aracı olarak anket kullanılmıştır. Anket soruları demografik özelliklerin belirlenmesi ve çalışanların örgütsel bağlılık türlerinin belirlenmesi sorularından oluşan iki bölümü içermektedir. Anketin ilk bölümünde sorulan sorular katılımcıların yaş, cinsiyet, eğitim durumunu belirlemeye yönelik olarak direkt sorulmuştur. İkinci bölümü ise, çalışanların örgütsel bağlılık türünü belirlemek için Meyer, Allen ve Smith'in (1993) geliştirdiği üç boyutlu "örgütsel bağlılık ölçeği" temel alınarak uygulanan soru formları oluşturmaktadır. Meyer, Allen ve Smith oluşturdukları örgütsel bağl1lık ölçeğinde duygusal bağl1lık, devam bağl1lığ ve normatif bağl1lık modellerinin her birini 6'şar soru ile ölçmektedir. $\mathrm{Bu}$ ölçeğin aslına "https://www.employeecommitment.com/" adresinden ulaşılmış, sorular Ek:1 deki şekilde Türkçeye çevrilmiştir. Aynı ölçek kullanılarak yapılan önceki çalışmalar taranmıştır. Wasti (2000) ölçeğin Türk çalışanlarına uygunluğunu 
çözümlemeye yönelik çalışmasında, örgütsel bağlılık boyutlarından duygusal bağlılığın alfa değerini 0,79 , devam bağlılığının alfa değerini 0,58 , normatif bağlılığın alfa değerini 0,75 olarak ortaya çıkarmıştır. Sarıdede'de (2004) yılında Allen ve Meyer ölçeğini direkt anket sorularına yansıtmış duygusal bağlılık alfa değerini 0,84 , devam bağlılığının alfa değerini 0,60 , normatif bağlılı̆̆ın alfa değerini 0,50 olarak ortaya koymuştur. Bu çalışmanın amacı için katılımcıların refleks cevaplar yerine gerçek tutumlarını ortaya koyan yanıtlar vermeleri önemlidir. $\mathrm{Bu}$ sebeple sorulardaki ifadeler sembolik analoji tekniğinden yararlanılarak dönüştürülmüştür. Sembolik analoji tekniği "benzer ya da birbirinin zıddı olan ya da açık bir biçimde ilişkili görülmeyen fikirler, teoriler, davranışlar, tutumlar, imgeler ya da nesneler arasında somut bağlantılar kurmaktır" (Sak, 2008). Sembolik analoji tekniği esasen bir anlam transferini amaçlamakta, kullanımı esnasında terimler direkt anlamlarından öte mecazi bir formda kullanılmaktadır. $\mathrm{Bu}$ teknik yardımıyla "birleştirilen düşünceler ya da kurumlar birbirlerine ne kadar uzak iseler, ortaya çıkan anlamın gerçeği ifade düzeyi o kadar yüksek olmaktadır" (Sak, 2008). Araştırmanın amacı için, çoktan seçmeli sorulardaki şıklar üç boyutlu örgütsel bağl1lık türünü ifade eden duygusal bağl1lık, normatif bağl1lık ve devam bağl1lı̆̆ına referans olacak durumlarla ve ifadelerle örtüştürülmüş, araştırmanın güvenilirliğini sağlamak için benzer anlamdaki sorular açık uçlu sorular ile tersten kodlanarak sorulmuştur. $\mathrm{Bu}$ araştırma için geliştirilen anket formu uygulama safhasından önce pilot olarak 25 katılımcı üzerinde uygulanmış, soru formunun yapı geçerliliğine, iç tutarlılığına ve madde analizine dönük istatistikî hesaplamalar yapılmıştır. Pilot uygulamada anket formundaki anlaşılmayan ifadeler belirlenip değiştirilmiş ve ölçeklerin sıralaması birbirini etkileme derecesine göre yeniden düzenlenmiş, doğrulayıcı faktör analizi yapılarak soru formları tamamlanmıştır.

Allen ve Meyer'in üç boyutlu örgütsel bağlllık ölçeği ifadeleri sembolik analoji ifadelerine çevrilirken, Clement'in (1983) analojik ifade oluşturma süreci safhaları izlenmiştir. Buna göre ilk aşamada Allen ve Meyer'in ölçeğindeki ifadeyi yansıtan analojik düşünce geliştirilmiş, ikinci aşamada analoji ilişkisini doğrulamak için ilişki geçerliliği eleştirel bir biçimde test edilmiş ve geçerlik doğrulanmış, üçüncü aşamada kişilere analojik durumu anlatmak ve tahmin edilebilir duruma getirmek için ifadeler dışsal etki ve farklı anlam yaratan diğer parametrelerden ayıklanmış, dördüncü aşamada ifadeler transfer edilmiştir.

\subsection{Veri Analizi}

Araştırmada, görüşme formundan elde edilen veriler araştırmacı tarafindan çözümlenerek çalışma öncesinde Allen ve Meyer'ın üç boyutlu örgütsel bağl1lık ölçeği temelinde oluşturulan kod sistemine göre kategorilere yerleştirilmiştir. Bu aşamada Meyer, Allen ve Smith'den (1993) uyarlanan örgütsel bağl1lık ölçeğinin sembolik analoji tekniğiyle ankete uyarlanması sonucunda oluşan soru formlarının güvenilirliğini test etmek için Cronbach Alpha değerleri incelenmiş, ölçek toplam değeri 0,882 bulunmuştur. Güvenilirlik için asgari değerin 0,700 olmasının yeterli oluşu (Büyüköztürk, 2011), oluşturulan soru formlarının güvenilir olduğunu söylemeyi mümkün kılmıştır. Ardından kodlar ve kategorilerin frekans ve yüzdeleri belirlenmiş, tablolaştırılarak yorumlanmıştır. 


\subsection{Bulgular}

Tablo 1: Cinsiyet

\begin{tabular}{|l|c|c|}
\hline & N & \% \\
\hline Erkek & 114 & 57 \\
\hline Kadın & 86 & 43 \\
\hline Toplam & 200 & 100 \\
\hline
\end{tabular}

Araştırmaya katılan özel sektör çalışanlarının \%57'si erkek, \%43'ü kadın, yaş ortalamaları ise 36 'dır.(Tablo 1). Tablo 2 'de gösterildiği üzere eğitim durumları $\% 51$ Üniversite, $\% 43$ Lise, \%5 Ortaöğretim mezunu, \%1'i ise okuma yazma öğrendikten sonra ilköğrenimine devam etmemiştir.

Tablo 2: Eğitim Durumu

\begin{tabular}{|l|c|c|}
\hline & $\mathbf{N}$ & $\mathbf{\%}$ \\
\hline Üniversite & 102 & 51 \\
\hline Lise & 86 & 43 \\
\hline Ortaöğretim & 10 & 5 \\
\hline Okur-yazar & 2 & 1 \\
\hline Toplam & 200 & 100 \\
\hline
\end{tabular}

Tablo 3: Yeteneklerin Transferi Eğilimi

\begin{tabular}{|l|c|c|}
\hline & $\mathbf{N}$ & $\mathbf{\%}$ \\
\hline Evet & 46 & 23 \\
\hline Hayır & 154 & 77 \\
\hline Toplam & 200 & 100 \\
\hline
\end{tabular}

Katılımcılara kullandıkları telefonlarının yerine aynı boyutta, aynı renkte ve aynı yazılım özelliklerine sahip yeni, garantili ve hiç kullanılmamış bir telefon verilmesinin teklif edildiği, fakat mevcut telefonlarındaki verilerin ve ayarların yeni telefona aktarılamayacağı söylenen bir durumda kalsalar takas teklifine ne cevap verecekleri sorulmuş, \%23 takas edeceğini, \%77 takas etmeyeceğini ifade etmiştir. Bulgu çalışanların özel hayatlarında yaşanmışlık bağlarına önem gösterdiğini, yeni bir seçeneğe her ne kadar cazip de olsa mesafeli durduklarını ortaya koymaktadır.

Tablo 4: Şahsi Kayıp-Örgütsel Bağımlılık Tercihi

\begin{tabular}{|l|c|c|}
\hline & N & \% \\
\hline Şahsi zararıma izin vermem & 124 & 62 \\
\hline Şahsi zararıma izin verebilirim & 76 & 38 \\
\hline Toplam & 200 & 100 \\
\hline
\end{tabular}


Katılımcılara iş yerinde yürütmekte oldukları bir projenin başarıya ulaşmadan önceki son safhasında, rakip firmanın yetkililerinden kendi özel hayatları ile ilgili bir koz öne sürülerek projeyi başarıya ulaştırmamaları yönünde bir tehdit alsalar nasıl davranış sergileyecekleri sorulmuş, \%38 firmanın hedeflerine ulaşması için şahsi itibarlarını tehlikeye atabileceğini, \%62 ise kişisel kayıp yaşamamak adına firmanın hedeflerine ulaşmamasını tercih edebileceklerini ifade etmiştir. Bu bulgu çalışanların kişisel kayıp durumları hâsıl olduğunda örgütsel kayba göz yumabileceklerini göstermektedir.

Tablo 5: Şahsi Kazanç-Örgütsel Bağımlılık Tercihi

\begin{tabular}{|l|c|c|}
\hline & $\mathbf{N}$ & $\mathbf{\%}$ \\
\hline Firma zararına izin vermem & 130 & 65 \\
\hline Firma zararına izin verebilirim & 70 & 35 \\
\hline Toplam & 200 & 100 \\
\hline
\end{tabular}

Katılımcılardan bir firmanın satın alma müdürü olduğunu ve alım yapacağı firmaları kendisi tarafından belirlenip bu konuda yönetime hesap vermediği bir durumu hayal etmeleri istenmiştir. Bu koşullar altında bir ürün grubunu, piyasa fiyatından satan bir firmadan mı, yoksa piyasa değerinden daha pahalı satan arkadaşının firmasından mı alacağı sorulan katılımcıların \%35'i arkadaşından, \%65'i en hesaplı buldukları firmadan alımı gerçekleştireceğini ifade etmiştir. Bu bulgu çalışanların örgütsel pozisyonlarını şahsi kazanç amacıyla kötüye kullanma eğilimlerinin düşük olduğunu gösterirken, kişilerin sergilediği tutumun örgütün kendilerinin sadakatini hak ettiği yönünde olduğunu söylemeyi mümkün kılmaktadır.

Tablo 6: Arkadaş Bağlılığı Eğilimi

\begin{tabular}{|l|c|c|}
\hline & $\mathbf{N}$ & $\mathbf{\%}$ \\
\hline Evet & 118 & 59 \\
\hline Hayır & 82 & 41 \\
\hline Toplam & 200 & 100 \\
\hline
\end{tabular}

Katılımcılara çalıştıkları iş yerinde yönetimin aldığı yeni bir karar sonucunda kendilerinin etkilenmediği fakat iş arkadaşlarının olumsuz olarak etkileneceği bir durum yaşandığında, durumun düzeltilmesi ve kararın geri çekilmesi için yönetim ile temas kurup kurmayacakları sorulmuş, \% 41'i bu kişi iş arkadaşı da olsa başkası için kendini riske atmayacağını, \%59'u yanlış anlaşılmayı düzeltmeye çalışacağını ifade etmiştir. Bu bulgu kurum içi iletişimin sağlanmasını önemseyen \%59'luk kısmın aynı zamanda normatif bağlılık eğilimi gösterdiğini ortaya koymaktadır. Kendilerine negatif etki yaratmadığı için müdahale etmeyeceklerini söyleyen \%41'lik kısmın iş yerinde arkadaşlık bağları zayıftır. 
Tablo 7: Adil Paylaşım Eğilimi

\begin{tabular}{|l|c|c|}
\hline & N & \% \\
\hline Adil paylaşırım & 104 & 52 \\
\hline Adil paylaşmam & 96 & 48 \\
\hline Toplam & 200 & 100 \\
\hline
\end{tabular}

Katılımcılara arkadaşıyla ortak aldıkları bilete ikramiye vurduğunu fakat kendisi söylemezse arkadaşının durumu asla öğrenmeyeceğini hayal etmeleri ve bu durumda ne yapacakları sorulmuş, \%52'si ikramiyeyi arkadaşıyla paylaşacağını, \%48'i arkadaşına söylemeden ikramiyeyi tek başına alacağını ifade etmiştir. Yüzdeler birbirine çok yakın olduğundan adil paylaşım konusunda kişilerin davranışlarına yön veren tutumların diğer parametreler ile netlik kazandığını söylemek mümkündür.

Tablo 8: Gönüllü Mesai Eğilimi

\begin{tabular}{|l|c|c|}
\hline & $\mathbf{N}$ & \% \\
\hline Evet & 102 & 51 \\
\hline Hayır & 98 & 49 \\
\hline Toplam & 200 & 100 \\
\hline
\end{tabular}

Katılımcılara eşleriyle akşam yemeğine çıkmayı planladıkları bir akşam kendilerinden son anda ek ödemesiz ve gönüllü olarak mesaiye kalmaları rica edilse nasıl bir tutum sergileyecekleri sorulmuş, \%51 oranında mesaiye kalma kararı, \%49 mesaiye kalmama kararı verileceği ifade edilmiştir. Sonuçlar birbirine çok yakın olmakla birlikte bu kararın verilmesine neden olarak mesaiye kalacağını söyleyenlerin \%51'lik kitlenin \%68'i başladıkları işi bitirmeyi bir yükümlülük olarak görerek normatif bağlılık sergilemekte, \%36's1 yöneticilerin gözüne girmek istedikleri yönünde cevap vererek devam bağlılı̆̆ına dönük tutum sergilemektedir. Mesaiye kalmama kararı verenlerin \% 74'ü ailelerini ihmal etmemek için bu kararı verdikleri yönünde cevaplar vererek, hayat öncelliklerinde işten çok ailenin bulunduğunu ifade etmektedir.

Tablo 9: İşe bağlılık

\begin{tabular}{|l|c|c|}
\hline & N & \% \\
\hline Mavi & 40 & 20 \\
\hline Siyah & 30 & 15 \\
\hline Sar1 & 26 & 13 \\
\hline Kırm1z1 & 18 & 9 \\
\hline Beyaz & 16 & 8 \\
\hline Yeşil & 16 & 8 \\
\hline Turuncu & 14 & 7 \\
\hline Kahverengi & 12 & 6 \\
\hline
\end{tabular}




\begin{tabular}{|l|c|c|}
\hline Mor & 12 & 6 \\
\hline Gri & 8 & 4 \\
\hline Pembe & 6 & 3 \\
\hline Lacivert & 2 & 1 \\
\hline Toplam & 200 & 100 \\
\hline
\end{tabular}

Katılımcılardan pazartesi gününü bir renkle örtüştürmeleri istendiğinde \%20'lik kısmı pazartesiyi mavi ile ilişkilendirmiştir. Toplamda umudu, samimiyeti, heyecanı, güveni, huzuru, sempatiyi ifade eden renkleri seçen \%68'lik katılımcı grubu haftanın ilk iş günü olan pazartesi gününe olumlu anlamlar yüklemekte ve duygusal bağlılık göstermektedir. \%32'lik kısım ise, karamsarlık, resmiyet, umutsuzluk, belirsizlik, kuralcılık anlamlarına gelen renklere yönelmektedir, bu bulgu sadece \%32'lik katılımcı grubuna göre pazartesinin olumsuz bir çağrışım yapması onların devam bağlılı̆̆ına yatkın olduğunu söylemeyi mümkün k1lmaktadır.

Tablo 10: İş Güçlüğü-Ücret Tercihi

\begin{tabular}{|l|c|c|}
\hline & N & \% \\
\hline Para & 96 & 48 \\
\hline Unvan & 104 & 52 \\
\hline Toplam & 200 & 100 \\
\hline
\end{tabular}

Katılımcılardan lunaparkta atış yapmak üzere olduklarını hayal etmeleri istenmiştir. Hedefte bulunan 2 kutudan birini vurduklarında yüklü miktar para alacakları, diğerini vurularsa "dünyanın en iyi atıcısı unvanı" ile rekorlar kitabına girecekleri bir durumda hangi kutuyu vurmak isteyecekleri sorulmuş, \%52 oranında unvan, \%48 oranında para tercih edilmiştir. Bu bulgu katılımcıların devam bağlılı̆̆ gösterseler de prim, ödül vb. teşvik uygulamaları olduğunda iş yerlerinde daha yüksek performans sergileme potansiyeli taşıyarak duygusal bağl1lığa eğilimli oldukları yönünde yorumlanmaktadır.

Tablo 11: İhtiyatlılık Eğilimi

\begin{tabular}{|l|c|c|}
\hline & $\mathbf{N}$ & $\mathbf{\%}$ \\
\hline Evet & 126 & 63 \\
\hline Hayır & 74 & 37 \\
\hline Toplam & 200 & 100 \\
\hline
\end{tabular}

Katılımcılardan sebepsiz yere patrondan azar işittiği ve aslında haklı gerekçesi olduğu bir anı hayal etmeleri ve o durumda kendini patrona karşı savunmak ile sessiz kalmak arasında hangisini tercih edecekleri sorulduğunda \%63 oranında kendilerini savunacakları, \%37 oranında duruma takılmadan işlerine devam edecekleri yönünde cevaplar alınmıştır. Kendini savunacağını söyleyen \%63'lük 
kitlenin kendilerini örgüte ait hissetmek ve kendilerini orada aktör olarak görme konusunda duygusal bağlılık eğilimleri olduğu söylenebilmektedir.

Tablo 12: İş yerindeki genel yüz ifadenizi en çok yansıtan emoji hangisidir?

\begin{tabular}{|c|c|c|}
\hline & $\mathbf{N}$ & $\%$ \\
\hline & 58 & 29 \\
\hline & 38 & 19 \\
\hline & 42 & 21 \\
\hline$\$ \$$ & 6 & 3 \\
\hline Toplam & 200 & 100 \\
\hline
\end{tabular}

Katılımcıların \%43'lük bölümü olumsuz anlama gelecek sembolleri tercih etmektedir, \%21'lik kısım iş yerinde öfkeli olduğunu, \%19'luk kısım ise iş yerinde mutsuz olduğunu açıklayan simgelere yönelirken sadece \%3'lük kısım para için çalıştığını açık biçimde sunmaktadır. Öte yandan sadece \%29'luk kısım net bir şekilde iş yerinde mutlu olduğu ifade edilmektedir.

Tablo 13: Daha İyi İş İçin Şehir Değişikliği

\begin{tabular}{|l|c|c|}
\hline & N & \% \\
\hline Başka şehre giderim & 68 & 34 \\
\hline Başka şehre gitmem & 132 & 66 \\
\hline Toplam & 200 & 100 \\
\hline
\end{tabular}

Katılımcılardan hâlihazırdaki işinden kariyer hedefiyle daha çok örtüşen ve daha yüksek maaşlı bir iş teklifi aldıkları fakat bu işi kabul ettiği takdirde, aile, arkadaşlar, tüm sevdiklerini arkada bırakacağı bir durumu hayal etmeleri istendiğinde \% 66 oranında bu teklifi kabul etmeyecekleri cevabı alınmıştır. Parametreler arasında mevcut iş yerleri koyulmadan tasarlanan bu soruda kişilerin özel hayat bağlarının mevcut işlerini sürdürmelerinde etkisinin yüksekliği ortaya çıkmaktadır. Öte yandan \%34'lük kısım net bir biçimde kariyer hedefine ulaşmak için özel hayatından feragat edebileceğini söyleyerek devam bağlılı̆̆ına yakın tutum sergileyecektir. 
Tablo 14: Aylık Gelir-İşe Devam

\begin{tabular}{|l|c|c|}
\hline & $\mathbf{N}$ & $\mathbf{\%}$ \\
\hline İşime devam ederim & 106 & 53 \\
\hline İşten ayrılırım & 94 & 47 \\
\hline Toplam & 200 & 100 \\
\hline
\end{tabular}

Katılımcılardan beklenmedik yerden yüklü bir mirasa sahip olduklarını hayal etmeleri istenmiş, yine de mevcut işlerinde devam edip etmeyecekleri sorulmuştur. Örneklemi oluşturan kitle \%53 oranında mevcut işlerine devam edeceğini dile getirmiştir. Bu kitlenin \%62'lik kısmı paranın devamı olmamasından dolayı bittiğinde iş bulamamaktan endişelendikleri için ayrılmayacakları yönünde yanıtlar vermiştir. Öte yandan işten ayrılacağını söyleyen \%47'lik kitlenin \%72'lik kısmı paraları varsa çalışmalarına gerek olmayacağını ifade eden açıklamalar yazmıştır. Mirastan elde edilen para ile iş kurabileceğini, bu nedenle işten ayrılacağını söyleyenler ise \%47'lik kitlenin sadece \%28'ini oluşturmaktadır.

\section{Tablo 15: Eski Örgüt-Yeni Örgüt Sadakati}

\begin{tabular}{|l|c|c|}
\hline & N & \% \\
\hline $\begin{array}{l}\text { Yeni işimde kendimi hemen } \\
\text { göstermeye çalışırım }\end{array}$ & 140 & 70 \\
\hline $\begin{array}{l}\text { Eskiyle bağlarımı hemen } \\
\text { koparamam }\end{array}$ & 60 & 30 \\
\hline Toplam & 200 & 100 \\
\hline
\end{tabular}

Katılımcılardan başarılı bir futbolcu olduklarını, yıllardır oynadıkları futbol kulübünden başka bir kulübe yeni transfer oldukları, şans eseri ilk karşılaşmanın eski takımları ile olduğu ve tüm yakın arkadaşlarının artık rakip olduğu bir durumda kendilerini hayal etmeleri istenmiştir. Gol atmak için çok çaba harcayıp harcamayacağı sorulan katılımcılardan $\% 70$ oranında evet cevabı alınmıştır. Bu cevap bir örgüte yeni katılan kişinin örgütsel bağlılık geliştirmek için yeterli vakit geçmemiş olmasına rağmen kendini göstermek ve başarısını kanıtlamak için yoğun oranda çaba harcamaya meyilli olduğu dolayısıyla katılımcıların \%70'inin kimliklerindeki bireysel hırs unsurunun etkisiyle yeni iş yerlerine sadık olacaklarını, \%30'luk kısım ise duygusal davranarak eski kuruma ve arkadaşlarına hemen rakip olamayacaklarını ifade etmektedir. 
Tablo 16: Özel Yaşam İle İlgili Kararlar Alırken İş Yaşamına Öncelik Tanıma Ĕgilimi

\begin{tabular}{|l|c|c|}
\hline & N & \% \\
\hline Öncelik özel yaşam & 134 & 67 \\
\hline Öncelik iş yaşamı & 66 & 33 \\
\hline Toplam & 200 & 100 \\
\hline
\end{tabular}

Katılımcılardan kendilerini yoğun duygularla yeni bir ilişkiye başlayıp, kısa bir zaman sonra hayatındaki kişinin aslında rakip firmanın önemli pozisyonunda çalışan ve ondan bilgi sızdırmak amacında olduğunu öğrenen bir kişinin yerine koymaları istenmiş ve bu şartlar altında ne yapacakları sorulmuştur. Katılımcıların \%36's1 bu bilgiyi öğrenmesine rağmen yoğun duygularına yenik düşüp ilişkiye devam edeceği yönünde, \%33'ü mevcut işine duyduğu bağlılıktan dolayı ilişkisini bitireceği yönünde, \%31'i ise kendini kandırılmış ve kullanılmış hissedeceğinden ötürü ilişkiyi sonlandıracağ1 yönünde cevap vermiştir. Bu bulgu bireylerin özel yaşam öncelikleri ile iş yaşamı öncelikleri karşı karşıya geldiğinde \%67 oranında şahsi davranarak özel yaşam temelli kararlar alacaklarını ortaya koymaktadır.

Tablo 17: İş Yaşamı İle İlgili Kararlarlar Alırken Özel Yaşama Öncelik Tanıma Eğilimi

\begin{tabular}{|l|c|c|}
\hline & $\mathbf{N}$ & $\mathbf{\%}$ \\
\hline Öncelik özel yaşam & 108 & 54 \\
\hline Öncelik iş yaşamı & 92 & 46 \\
\hline Toplam & 200 & 100 \\
\hline
\end{tabular}

Katılımcılardan çalışma koşullarının oldukça rahat olduğu ve kendini oradayken iyi hissettiği işine devam ederken aileye yeni bir üye katıldığını, bu yeni durumda masrafların artması ile mevcut işteki gelirin yetersiz kaldığını ve eşinin de durumdan sürekli şikâyet ettiğini imgelemeleri istenmiş ve bu koşullar altında ne yapacakları sorulmuştur. \%54 lük oranda katılımcı mevcut işlerinde her şey yolunda olsa da, ihtiyaçtan dolayı daha yüksek maaşlı bir iş aramaya başlayacaklarını, dolayısıyla aile söz konusu olduğunda örgütsel bağlılıklarının zayıflayacağını ifade etmişstir. 
Tablo 18: İş Yerindeki Durumunuz Bir Çizgi Karakter Olsa Ne/Kim Olurdu?

\begin{tabular}{|l|c|c|}
\hline & N & \% \\
\hline Çalışkan karakterler & 86 & 43 \\
\hline Miskin karakterler & 72 & 36 \\
\hline Uyanık karakterler & 42 & 21 \\
\hline Toplam & 200 & 100 \\
\hline
\end{tabular}

Katılımcılara yöneltilen bu açık uçlu soruda \%43 kendinin iş yerindeki halini Atom Karınca, Arı Maya, Tazmanya Canavarı, Süpermen gibi çalışkan, güçlü ve hızla sonuca ulaşan karakterler ile ifade etmekte, normatif bağlılığa yakın durmaktadır. \%36'lık k1sım ise Garfield, Snoopy gibi miskin ve yavaş hareket eden keyfine düşkün karakterleri kendileriyle örtüştürerek devam bağlılı̆̆ına eğilimlerini ortaya koymaktadır. \%21 oranda ise Çakal Karlos, Road Runner, Tweety gibi uyanık, zararlardan ve olumsuz durumlardan kolayca sıyrılan, işlerini kestirme yoldan halleden karakterlerle benzeşim yaratarak direkt ifade etmeseler de yine devam bağlılığına yakın bir bireysel kimliğe sahip olduklarını ifade etmektedirler.

Tablo 19: İtaat Ĕgilimi

\begin{tabular}{|l|c|c|}
\hline & $\mathbf{N}$ & \% \\
\hline Amirime jest yaparım & 66 & 33 \\
\hline $\begin{array}{l}\text { Amirime jest yapmaya } \\
\text { gerek duymam }\end{array}$ & 134 & 67 \\
\hline Toplam & 200 & 100 \\
\hline
\end{tabular}

Katılımcılardan kendini iki kişilik bir tatil bileti kazanan fakat belirlenmiş olan tarihlerde yurtdışında olacağı için, bileti birine teklif etmesi gereken birinin yerine koymaları istenmiş, bu durumda bileti iş yerindeki amire mi, yoksa bir yakın akrabaya mı verecekleri sorulmuştur. \%67 oranında akraba şıkkı seçilmiştir. \%33'lük bir kısım ise iki kişilik tatil biletini amirlerine teklif edeceğini ifade etmiştir. Amire itaat eğilimi üç bağlılık türünde de bulunan bir parametredir. Fakat bunu ortaya koyma amacı bireylerin ne tür bağlılı̆ga sahip olduğunu ortaya koymaktadır. Katılımcilara sorulan neden sorusuna verilen yanıtlar, Bileti amirine vereceğini ifade edenlerin \%72'sinin onun gözüne girmek ve sempati kazanmak amacıyla olduğunu, \%28'inin ise yöneticilerinin çok çalıştığı, iyi bir insan olduğu yahut tatili hak ettiği yönünde cevaplar vermiştir. Bu durum işgörenlerin yöneticileri ile iyi geçinme arzularının nedeninin büyük oranda devam bağlılı̆̆ına sahip olmalarından ileri geldiğini ortaya koymaktadır. Öte yandan bileti bir akrabalarına vereceğini söyleyenlerin sadece \%12'lik kısmı yöneticilerinin iyi bir insan olduğunu fakat bu jestin yaranma çabası olarak algılanmasından çekindikleri için bu davranışı gerçekleştirmeyecekleri yönünde yanıt vermektedir. 
Tablo 20: Duygusal-Rasyonel Seçim

\begin{tabular}{|l|c|c|}
\hline & N & \% \\
\hline Duygusal & 92 & 46 \\
\hline Rasyonel & 108 & 54 \\
\hline Toplam & 200 & 100 \\
\hline
\end{tabular}

Katılımcılara çocukluğundan beri hayalini kurduğu araba için gereken parayı denkleştirip aracı satın almaya gittiği anda satış elemanının teknik donanımı daha üstün ve daha tercih edilen bir modelin kampanyadan dolayı indirimde olduğunu ve o aracın tavsiye edildiği durumda kendilerini hayal etmeleri istenmiş ve ne karar verecekleri sorulmuştur. \%46'lık kısım hayalindeki aracı almakta 1srar edeceğini, \%54'lük kısım ise fikrini değiştirip diğer araca yönleneceğini ifade etmiştir. Bu bulgu anlık ödül ve teşvik gibi kazanımlarla bireylerin hayallerinden vazgeçmeye meyilli oldukları, normatif bağlılıklarının zayıf olduğu yönünde yorumlanmaktadır.

Tablo 21: Eşitlik/Adalet Eğilimi

\begin{tabular}{|l|c|c|}
\hline & N & \% \\
\hline Terfi için haksızlık yapmam & 144 & 72 \\
\hline Terfi için haksızlık yaparım & 56 & 28 \\
\hline Toplam & 200 & 100 \\
\hline
\end{tabular}

Katılımcılardan iş yerinde terfi almak için bir proje yazılması istendiği ve terfinin tüm çalışanlar arasından en iyi seçilen projeye verileceğinin söylendiği bir koşulda kendileri hayal etmeleri istenmiştir. Sonuçların açıklanmasından bir gece önce şans eseri gece mesaisinde kimse yokken sıralamayı gördükleri ve kendilerinin ikinci sırada olduğu, sıralamayı değiştirmenin bir tuşlarıyla mümkün olduğu ve kimsenin bunu bilmeyeceği bir durumda kalınsa ne yapılacağı sorulmuştur. Örneklemin \%28'i sıralamayı değiştireceklerini ifade ederken \%72'si hiçbir oynama yapmayacaklarını söylemiştir. Bu bulgu bu koşullar altında bireylerin normatif bağlılığa eğilimli olduğunu ortaya koymaktadır.

Tablo 22: Kişisel Önem Eğilimi

\begin{tabular}{|l|c|c|}
\hline & N & \% \\
\hline Olumlu & 84 & 42 \\
\hline Olumsuz & 116 & 58 \\
\hline Toplam & 200 & 100 \\
\hline
\end{tabular}

Amiriniz çocuğunu okuldan almanız için size görev verse tutumunuz ne olurdu diye sorulan katılımcilardan \% 42'si olumlu bir tutum sergileyeceklerini, neden olarak da amirlerinin tüm çalışanlar arasında yalnızca kendilerini güvenilir bulduğunu düşünecekleri, yapılan işin sorumluluk gerektiren bir iş olmasından ötürü mutlu 
hissedecekleri yönünde cevaplar verirken, $\% 58$ bu durumda olumsuz düşüneceklerini, fazladan ve gereksiz bir şekilde efor sergileyecekleri için mutsuz olacakları yönünde yanıtlar vermişlerdir. Dolayısıyla bu bulgu katılımcıların \%42'sinin duygusal bağlılık geliştirmeye uygun kimlik özellikleri taşıdığını göstermektedir.

\section{Tablo 23: Takdir Beklentisi}

\begin{tabular}{|l|c|c|}
\hline & $\mathbf{N}$ & $\mathbf{\%}$ \\
\hline Evet & 176 & 88 \\
\hline Hayır & 24 & 12 \\
\hline Toplam & 200 & 100 \\
\hline
\end{tabular}

Örneklemi oluşturan katılımcılara tüm çalışma arkadaşlarının doğum günlerini kendinin organize edip, o günlerde eğlenceli kutlamalar yapılmasını sağladığı ve herkesin kendisine müteşekkir olduğu bir iş yerinde, kendi doğum gününün hiçbir iş arkadaşı tarafından hatırlanmaması durumunda tutumunun ne olacağı sorulmuştur. Sadece \%12 oranında umursamam yanıtı verilirken, \%88'lik kısım umursayacağını ifade etmiştir. Umursayacağını söyleyen kitle arasında tepki olarak, artık kimsenin özel gününü kutlamayacağı, üzüntüden bir kaç gün izin alacağ1, arkadaşlarının hepsiyle arasına mesafe koyacağı yönünde cevaplar alınmıştır. Bu bulgu duygusal bağlılık türünü sergileyen çalışanların durumsal olarak örgütsel bağlılık eğilimlerinin topyekûn yok olabilme potansiyeli taşıdığını göstermektedir.

\section{Sonuç}

Çalışanların işe devam, yüksek performans sergileme, kurum içi olumlu iletişim, gönüllü çalışma, inisiyatif alma gibi davranışlarının tümü örgütsel bağlılık çıktısı olarak gösterilmektedir. Fakat bu davranışlara neden olan duygular, fikirler ve koşullar birbirinden farklı hatta zıt anlamlar taşıyabilmektedir. Diğer bir deyişle aynı örgütsel bağlılık davranışının nedenleri, farklı bireylerin iç dünyası temelli olarak birbirine taban tabana zıt amaçlarla ortaya çıkabilmektedir. Kimi zaman bir kurumda uzun süre çalışmış olmaktan mütevellit duygusal bağlılık gelişirken, kimi zaman bir kurumda yeni işe başlayan bir kişi normatif bulduğundan, ya da kısa sürede ek kazanım elde edebilmek amacıyla duygusal bağlılık davranışlarının neredeyse tümünü sergileyebilmektedir. Yani, kurumda örgütsel bağlılığ1 yüksek birey davranışlarının tümünü sergileyen kişi aslında örgütsel bağlılığı en düşük kişi olabilme ihtimalini barındırabilmektedir. Belli bir tutumun çıktısı olarak ele alınan davranışların çoğu zaman farklı sebepleri olabilmektedir. Diğer taraftan, bireylerin davranışlarına her zaman iç dünyaları yön vermemekte dışsal parametreler anlık davranış değişikliklerine yol açabilmektedir.

$\mathrm{Bu}$ çalışma yansıtma tekniğinden yararlanarak bireylerin hangi türde örgütsel bağlılık geliştirmeye yatkın olduğunu keşfederken, bu bağlılık türünü 
geliştirmelerinde örgütsel uygulamaların tesirinin yanı sıra bireysel kimlik unsurlarının ve dışsal parametrelerin davranış değişikliği yaratma etkisini de göz ardı etmemektedir. Çalışma sonuçları bireylerin doğrudan sorularda duygusal bağl1lık türünde davranışlar sergilediklerini ifade etseler de, belli bir durum içinde kendilerini hayal etmeleri istendiğinde devam bağlılığını gösterdiklerini ortaya çıkarmaktadır. Başka bir deyiş̧le araştırma, örgütsel bağlılık davranışının türünün yüksek oranda dış etkenler vasıtasıyla biçimlendiğini göstermektedir. $\mathrm{Bu}$ sonuç, genellikle halkla ilişkiler alanında yapılan kurum içi iletişim, motivasyon çalışmalarının yerindeliğini göstermektedir. Zira kurumların sunduğu imkânlar/imkânsızlıklar ve kurum iklimi çalışanların örgütsel bağlılık türünü etkileyen en önemli etken olarak kendini göstermektedir.

Araştırma sonuçları kişilerin örgütsel bağlılığını yüksek düzeyde etkileyen diğer parametre olarak aileyi göstermektedir. Çalışanlar büyük oranda ailevi öncelikleri göz önünde bulundurarak; istenmeyen koşullar altında çalışılan işe devam bağlılığ gösterebilmekte, kimi zaman ise daha iyi iş tekliflerini reddetme yahut yöneticileri ile sempatik iletişim kurabilme şansına karşın ailelerini tercih etme davranışı göstermektedir. Bu durum her ne kadar örgütsel bağlılık araştırmalarından azade ele alınsa da, kurum kültürünü ailenin bir prototipi şeklinde biçimlendiren işletmelere avantaj sağlayacaktır.

Araştırmada ortaya çıkan sonuç ise çalışanların örgütsel bağl1lık davranışlarında kayıp/kazanç asimetrisi bulunmasıdır. Kişiler farklı koşullar sunulduğunda bireysel kazanç sağlama ihtimalinde örgütsel kazanımı seçerken, bireysel kayıp olasılığına karşın örgütün zarar etmesini tercih etmektedir. Bu eğilime temel oluşturan, kişilerin kimliklerinde bulunan ahlaki kodlardır. Çalıştıkları kurumun zararına olacak şekilde bireysel çıkar sağlamayacağını ifade eden çalışanlar, başka koşullar altında kurumun zararına olacak olsa dahi bireysel zarar etmekten kaçınacak şekilde davranmaktadır. Başka bir deyişle çalışanların örgütsel sadakati keyfî çıkar durumlarında yüksek iken, zaruri olarak değerlendirdikleri kişisel zarar durumlarında kişiler örgütsel sadakati düşük davranışlar göstermektedir.

Çalışanların örgütsel bağlılık eğilimlerinde iş hayatı ile ilgili kararlar ile özel hayat ile ilgili kararlar alınırken yine bir kayıp/kazanç asimetrisi ortaya çıkmaktadır. Buna göre, özel hayat ile ilgili kararlar alınırken, örgütsel bağlılık eğilimi düşük iken, örgütsel bağll1ık söz konusu olduğunda özel yaşama öncelik tanıma eğilimi bireysel fayda sağlanan durumlarda düşük, bireysel kayıp durumlarında yüksektir.

Çalışanların büyük oranda unvan, itibar, terfi gibi bireysel kariyer hedeflerinin kurumsal amaçlardan önde tutulması araştırmadan çıkan bir diğer sonuçtur. Dolayısıyla kişiler duygusal ya da normatif bağl1lık türünde algılanan davranışlar sergilese de kimi zaman amaçları bireysel hedeflerine ulaşmak olmakta ve esasen devam bağlılığına sahip bulunmaktadırlar. Dışsal etkenlerden en az etkilenen bağl1lık türü olan normatif bağlılığa sahip işgörenler dahi, kurum içi motivasyon araçları azaldığında devam bağlılığına yönelebilmektedir. Bu anlamda örgütsel bağl11ı her ne kadar bireysel kimlik ile yakından ilişkili bir kavram olsa da, yapılan 
iş ile ilgili güdüleyiciler çalışanların bağlılık düzeyinde ve bağlanma türlerinde dönüşüm yaşanmasına yol açmaktadır.

Literatürde duygusal bağlılık yöneticiler tarafından en çok istenen örgütsel bağlılık türü olarak gösterilmesine rağmen, araştırma sonuçları duygusal bağlılığın devam bağlılığ 1 ve normatif bağlılığa oranla daha değişken ve hatta tutarsız davranışlar sergilenmesine neden olduğunu ortaya çıkarmaktadır. Yaptığı işe değer atfederek yapan birey inancını kaybettiği anda performansı düşmekte, iş yerinde kendini aile ortamındaymışçasına hisseden ve bundan dolayı verimli olan birey bu durumun zıddı olarak yorumladığı ilk etkide aksi yönde davranmaya meyletmektedir. Dolayısıyla araştırma sonuçları yönetimler tarafından çalışanlarda oluşturulmaya çalışılan bağlılık türünün duygusal bağlılıktan ziyade örgüt içi iletişime ortalama düzeyde önem veren kurumlar için normatif bağlılığa doğru evrilmesi gerektiğini göstermektedir. Diğer taraftan, örgütsel iletişim ve motivasyon konusunda kendini her geçen gün geliştirme vizyonuna sahip kurumlar için -yöneticiler tarafından en az tercih edilen- devam bağlılığı tüm bağlılık türlerine oranla örgütsel hedeflere ulaşmada en yüksek performansın sergilenmesini sağlayarak iç halkla ilişkiler çalışmalarına yeni açılımlar sunma potansiyeline sahiptir.

\section{KAYNAKÇA}

Afşar, S. T. (2011). "Çalışma Yaşam Kalitesinin Örgütsel Bağlılık Düzeyi Üzerindeki Etkisi: Devlet ve Vakıf Üniversitelerinde Çalışan Akademisyenler Üzerine Nicel Bir Araştırma".Doktora tezi, Ankara: Hacettepe Üniversitesi Sosyal Bilimler Enstitüsü.

Allen, N. J., and Meyer, J. P. (1990). "The Measurement And Antecedents of Affective, Continuance And Normative Commitment To The Organization", Journal of Occupational and Organizational Psychology/, 63(1), 1-18.

Allen, N. J., and Meyer, J. P., (1996). "Affective, Continuance, And Normative Commitment To The Organization: An Examination Of Construct Validity", Journal of Vocational Behavior. 49, 252-276.

Büyüköztürk. Ş., (2011). "Sosyal Bilimler İçin Veri Analizi El Kitabı", Ankara: Pegem Akademi.

Becker, S., (1960). "Notes on the Concept of Commitment", The American Journal of Sociology, http://www.jstor. com (Erişim tarihi:10 Mayıs 2019).

Davis, K., Newstrom W., (1989). "Human Behavior at Work: Organizational Behavior", New York: McGraw Hill.

DeLoria, J. E., (2001). "A Comparative Study of Employee Commitment: Core and Contract Employees" Virginia Üniversitesi Politeknik Enstitüsü İnsan Gelişimi Ana Bilim Dalı, http://www.psyc.vt.edu, (Erişim tarihi: 12 Şubat 2019).

Doğan, S., \& Kılıç, S., (2007). "Örgütsel Bağlılı̆̆ın Sağlanmasında Personel Güçlendirmenin Yeri ve Önemi", Erciyes Üniversitesi İktisadi ve İdari Bilimler Fakültesi Dergisi, (29) 37-61.

Gürbüz, S., (2006). "Örgütsel Vatandaşlık Davranışı İle Duygusal Bağlılık Arasındaki İlişkilerin Belirlenmesine Yönelik Bir Araştırma", AİBÜ-İ̈BF Ekonomik Ve Sosyal Araştırmalar Dergisi, 3(1), 48-75. 
Hague, P., Jackson, P., (1999). "Market Research: A Guide to Planning, Methodology and Evaluation", London: Kogan Page.

Kaygısız, A., (2012). "İlköğretim Öğretmenlerinin Örgütsel Bağlılık Düzeyleri Ve Karara Katılma Durumları Arasındaki İlişki Kütahya Örneği", Yüksek Lisans Tezi, Eskişehir: Osmangazi Üniversitesi Eğitim Bilimleri Enstitüsü.

Koll O, Won Wallpach, S. ve Kreuzer, M., (2010). "Multi Method Research on ConsumerBrand Associations: Comparing Free Associations, Storytelling And Collages", Pschology and Marketing, 27 (6), 584-602.

Meyer, J. P., Allen, N. J., and Smith, C. A., (1993). "Commitment to Organizations and Occupations: Extension and Test of a Three-component Model", Journal of Applied Psychology, 78, 538-551.

Mir, A., Mosca, R., (2002). "The New Age Employee: An Exploration Of Changing Employee - Organization Relations, Public Personnel Management", (2) 31, 187-200.

Obeng, K., Ugboro, I., (2003). "Organizational Commitment Among Public Transit Employees: An Assessment Study", Journal of the Transportation Research Forum, 2 (57), 83-98.

Özcan, B., (2011). "Örgüt Kültürü ve Örgütsel Bağlılık İlişkisi: Bankacılık Sektöründe Bir Araştırma", Yüksek Lisans Tezi, Denizli: Pamukkale Üniversitesi Sosyal Bilimler Enstitüsü.

Sak, U., (2008). "Yaratıcı Düşünme Teknikleri", Eskişehir: Anadolu Üniversitesi Yayınları.

Starnes, B., Truhon, S., (2006). "A Primer on Organizational Commitment. Human Development an Leadership Division, http://asqhdandl.org/index.html.(Erişim tarihi:12 Haziran 2019).

Steers R., (1977), "Antecedents and Outcomes of Organizational Commitment", Administrative Science Quarterly, 22(5), 46-56.

Steiger, J., (2007). "Understanding The Limitations Of Global Fit Assessment in Structural Equation Modeling". Personality and Individual Differences, 42 (5), 893-898.

Wasti, S., (2003). "Organizational Commitment, Turnover Intentions And The Influence Of Cultural Values", Journal of Occupational Psychology, 76, 303-321.

Wasti, S., (2000a). "Örgütsel Bağlılığı Belirleyen Evrensel ve Kültürel Etmenler: Türk Kültürüne Bir Bakış, içinde Türkiye'de Yönetim, Liderlik ve İnsan Kaynakları Uygulamaları, Ankara: Türk Psikologlar Derneği Yayınları, 201-224.

Wasti, S., (2000b). "Meyer ve Allen'in Üç Boyutlu Örgütsel Bağlılık Ölçeğinin Geçerlilik ve Güvenilirlik Analizi”, 8. Ulusal Yönetim ve Organizasyon Kongresi: 401-410.

Wiener, Y., (1982). "Commitment In Organization A Normative View", Academy Management Review, ( 7) 3, 418-428.

Zaltman, G., (2014). "Tüketici Nasıl Düşünür?". İstanbul: MediaCat.

Zangaro, G., (2001). "Organizational Commitment: A Concept Analysis", Nursing Forum, 36 (2), http://www.ebscohost.com, (Erişim tarihi: 25 Mart 2019). 


\section{Ek 1: Örgütsel Bağlılık Ölçeği}

\section{Duygusal Bağlılık Ölçeği}

1. Meslek hayatımın geri kalan kısmını bu kurumda geçirmek beni çok mutlu eder.

2. Bu kurumun sorunlarını gerçekten kendi sorunlarım gibi görüyorum.

3. Bu kuruma yönelik güçlü bir aidiyet hissetmiyorum.

4. Bu kuruma karşı duygusal bağl1lık hissetmiyorum.

5. Bu kurumda kendimi "ailenin bir parçası" gibi görmüyorum.

6. Bu kurumun bende kişisel bir yeri bulunmaktadır.

\section{Devam Bağlılığı Ölçeği}

1. Şimdi bu kurumda çalışıyor olmam, kendi isteğimden çok şartların bunu gerektirmesindendir.

2. Ne kadar istesem de şu anda bu kurumdan ayrılmak benim için çok zor.

3. Şu anda işimden ayrılacak olsam, hayatımda birçok şey alt üst olur.

4. Bu işten ayrılmamı düşündürecek seçenekler oldukça azdır.

5. Eğer bu kuruma kendimden çok şey katmamış olsaydım, başka yerde çalışmayı düşünebilirdim.

6. Bu işten ayrılmanın olumsuz sonuçlarının başında gelen şey, uygun iş alternatiflerimin kıtlığıdır.

\section{Normatif Bağlılık Ölçeği}

1. Bu işte çalışmaya devam etmek için yöneticilerime karşı bir minnet borcu hissetmiyorum.

2. Bu işten ayrılmak benim yararıma olsaydı da şu anda buradan ayrılmanın doğru olmadığını düşünüyorum.

3. İşimden şu anda ayrılacak olsam kendimi suçlu hissederim.

4. Bu kurum benim sadakatimi hak ediyor.

5. İş arkadaşlarıma olan bağlılığımdan ötürü işten ayrılmayı düşünmem.

6. Kurumuma çok şey borçluyum. 